\title{
Kimberley marine biota. Historical data: introduction and methods
}

\author{
Alison Sampey ${ }^{1 *}$, Clay Bryce', Stacey Osborne' and Albert Miles ${ }^{1}$ \\ 1 Department of Aquatic Zoology, Western Australian Museum, Locked Bag 49, Welshpool DC, \\ Western Australia 6986, Australia. \\ * Email: alison.sampey@hotmail.com
}

\begin{abstract}
The Kimberley region is currently undergoing substantial growth in industrial and general human use. The region is recognised as relatively pristine with a high diversity of habitats and species, but there is little published information on the marine biodiversity. Australian museums and herbaria are the repositories of species diversity datasets and voucher specimens collected over many decades (1880s to present). We have collated data on marine plants, sponges, cnidarians (predominately hard and soft corals), free living worms (predominately polychaetes), crustaceans, molluscs, echinoderms, brachiopods, ascidians and fishes from five Australian natural science collections. We identified $>50,000$ specimen records of approximately 6,000 shallow water marine species from the Project Area. The scope and methods adopted for this project are outlined here.
\end{abstract}

KEYWORDS: natural history collections, species inventory, Kimberley Project Area, baseline, NW Australia, biodiversity

\section{INTRODUCTION}

Knowing which species occur in an area is fundamental to many aspects of biological, conservation and environmental research, providing a baseline dataset to inform conservation and policy decisions, as well as to monitor both human and climate induced change (O'Connell et al. 2004; Sloan and Bartier 2009; Pyke and Ehrlich 2010). As such, it is vital information for the successful management of an area, including the development of marine protected areas and the preparation of environmental impact assessments. The study of taxonomy underpins this endeavour as it is the discipline responsible for defining, describing and understanding what constitutes a species and therefore informs distribution patterns (Cotterill 1995; Boero 2010).

Museums and herbaria are the repositories of species diversity datasets and voucher specimens (Cotterill 1995; Ponder et al. 2001; Sloan and Bartier 2009; Pyke and Ehrlich 2010; Appeltans et al. 2012; Huisman and Miller 2013). These collections provide a permanent record of the presence of a species in space and time (Cotterill 1995). The importance of natural science collection data to support biodiversity research and conservation planning is being increasingly recognised (Pyke and Ehrlich 2010). However, there are limitations to the available data, including bias in collecting effort (both taxonomic and geographic), taxonomic ambiguity and inadequate or poorly defined spatial coverage (Ponder et al. 2001; Funk and Richardson 2002; Graham et al. 2004).

The northern Australian coastline is recognised as having been exposed to minimal human impact (Halpern et al. 2008). Biodiversity is likely to be high in the region and a gradient in species diversity has been shown for a number of taxa (fishes, corals and echinoderms) along the Western Australian coastline, with higher diversity of species occurring in lower latitudes, including the Kimberley (Marsh and Marshall 1983; Wilson and Allen 1987; Veron and Marsh 1988; Hutchins 1999). However, there are few publications on species present in the region and much of this information is contained in specialist taxonomic literature. Currently, the region is undergoing substantial growth in industrial and other human use, including oil and gas extraction, fishing, aquaculture, and tourism (Wood and Mills 2008) and proposed marine protected areas (Department of Environment and Conservation 2009). Baseline marine biological data to characterise the values and assets in the region are required (Wood and Mills 2008).

The Western Australian Museum (WAM) has undertaken ten marine biological expeditions to locations within the Kimberley region since 1976 (Western Australian Museum 1981; Berry 1986; 
Wells 1989; Morgan 1992; Berry 1993; Wells et al. 1995; Walker et al. 1996; Bryce et al. 1997; Walker 1997; Bryce 2009). These surveys have visited many areas of the Kimberley coast, inshore islands, and continental shelf edge atolls with varying taxonomic, spatial and temporal coverage. The specimens collected during these expeditions, along with those from other surveys, or from incidental collecting over the last century (1880s to present), are housed in Australian natural science collections, primarily in Western Australia. However, the majority of these datasets and their interpretation are not readily accessible to resource managers and researchers interested in the marine biological values of the region. To address this gap in our knowledge the WAM instigated an extensive data compilation of marine species (excluding vertebrates except for fishes) known from the region.

\section{AIMS}

To collate the records of shallow water $(<30 \mathrm{~m})$ marine flora and fauna (restricted to fishes and invertebrates) from the Kimberley Project Area as defined below, with relevant associated voucher specimens lodged in Australian natural science collections (1880s-2009), and to provide commentary on general trends in diversity patterns and collection gaps, both spatial and taxonomic, for these taxa.

\section{METHODS}

\section{STUDY AREA, TAXONOMIC AND COLLECTION SCOPE}

The Kimberley Project Area (henceforth 'Project Area') is defined by the coordinates $19.00^{\circ} \mathrm{S}$ $121.57^{\circ} \mathrm{E} ; 1^{\circ} .00^{\circ} \mathrm{S} 118.25^{\circ} \mathrm{E} ; 12.00^{\circ} \mathrm{S} 129.00^{\circ} \mathrm{E} ; 12.00^{\circ} \mathrm{S}$ $121.00^{\circ} \mathrm{E}$, with the coastline forming a natural inshore boundary. This irregular polygon stretches north along the coast from Cape Jaubert, south of Broome, to the Western Australia/Northern Territory border, and extends westward beyond the $1000 \mathrm{~m}$ bathymetric contour to include the continental shelf edge atolls (Hibernia Reef to Imperieuse Reef, northernmost to southernmost respectively) of the Sahul Shelf (Figure 1). Wilson (2014) has reviewed the habitats, geology and historical exploration of the Project Area.

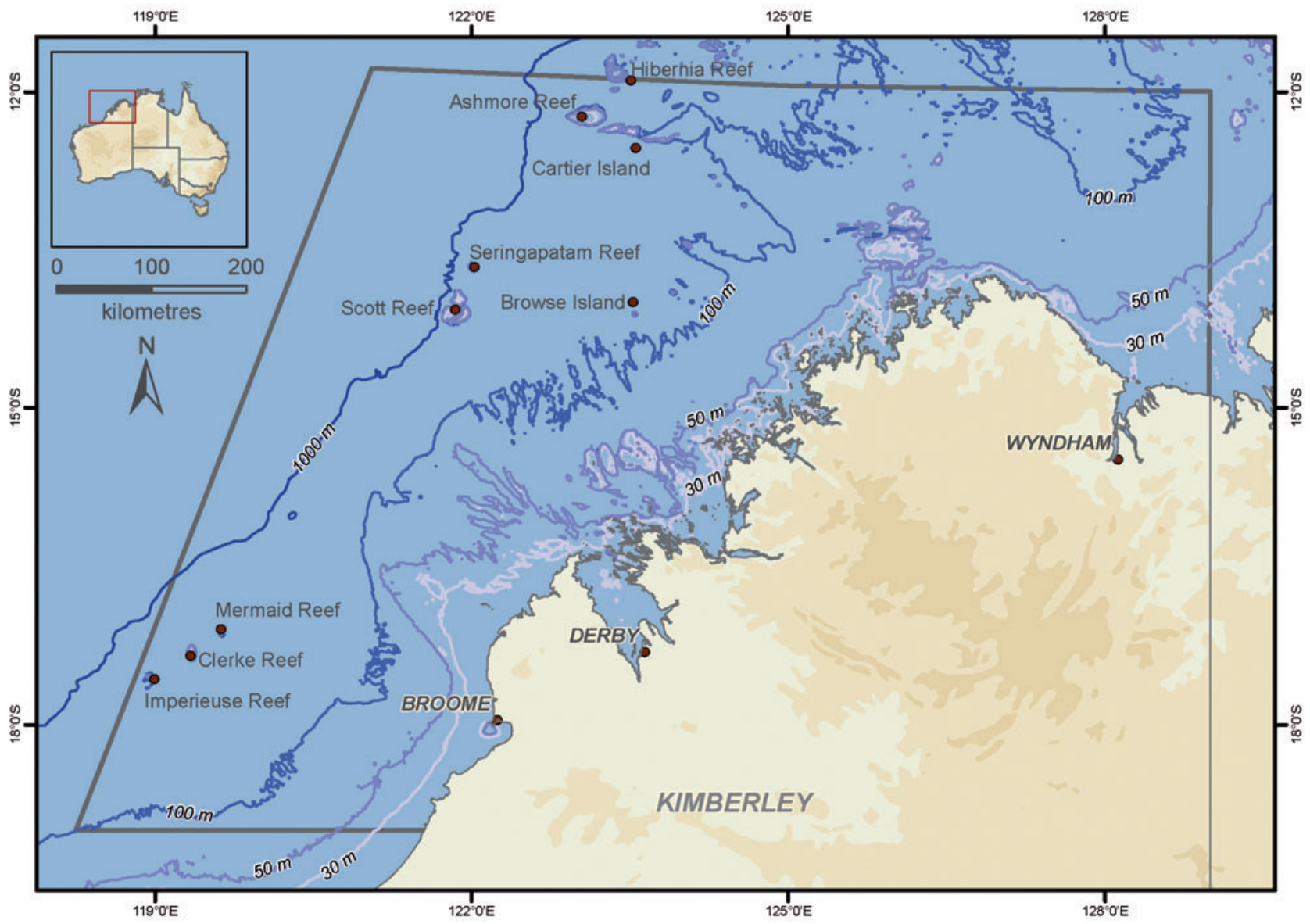


The taxonomic groups included marine plants (seagrasses, mangroves and macroalgae), sponges (Porifera), cnidarians (predominately hard corals with limited data on soft corals and non-anthozoan groups, such as hydroids, sea pens and sea jellies), free living worms (predominately polychaetes), crustaceans (mainly decapod crustaceans and barnacles with some data on isopods, amphipods and stomatopods), molluscs (predominately macromolluscs $>10 \mathrm{~mm}$ ), echinoderms, brachiopods, bryozoans, ascidians, and fishes. Henceforth our category of 'other marine invertebrates' includes non-polychaete worms (such as sipunculans, oligochaetes, flatworms, and leaches), cnidarians other than soft and hard corals (such as sea pens, zoanthids, hydroids and sea jellies), bryozoans, brachiopods and ascidians.

Data were sourced from published and unpublished species records, which are registered specimen vouchers maintained in natural science collections and databases from the Western Australian Museum (WAM), the Western Australian Herbarium (WAH), the Museum and Art Gallery of the Northern Territory (MAGNT), the Queensland Museum (QM) and the Australian Museum (AM). WAM collections were searched specifically for specimens collected from the Project Area. Voucher specimens not registered were added to a Project database, a copy of the existing Aquatic Zoology collection databases. For data sourced from the other institutions we relied on those already digitised in their respective databases; it is possible that unregistered material from the Project Area may reside in their collections and in overseas collections. If significant collections are available in overseas collections these will be referenced in the individual taxon papers.

The data from seven published manuscripts (Berry 1986; Johnstone 1990; Berry 1993; Brown and Skewes 2005; Russell et al. 2005; Willan 2005; Bryce 2009) and six unpublished reports (Wells 1989; Morgan 1992; Wells et al. 1995; Walker et al. 1996; Bryce et al. 1997; Walker 1997) were digitised with listed species names and locations added into the Project database (Appendix 1). Data from one additional survey report containing mangrove and mollusc species lists from a 1976 expedition to the Admiralty Gulf (Western Australian Museum 1981) were used but were not digitised into the project database.

The Project included records of marine and estuarine floral and faunal species collected in shallow waters $(<30 \mathrm{~m})$. This decision was made for two reasons. Firstly, the majority of the expeditions were intertidal and/or conducted on SCUBA to depths of $30 \mathrm{~m}$. Secondly, the resources and timeframes of the project did not allow for inclusion of deep water species data.

\section{TAXONOMIC CONSIDERATIONS}

Nomenclatural changes are common in biology as a species name represents a hypothesis that can be revised as new information (e.g. morphological, genetic, behavioural, distributional) becomes available (Gaston and Mound 1993). Taxonomy is usually poorly resourced, which influences the quality and maintenance of taxonomic datasets (Cotterill 1995). We identified a number of nomenclatural issues, including:

- misspellings;

- misidentifications;

- names that, subsequent to the initial examination and identification, had been synonymised or revised or for which the taxonomic concept of the species had changed and it was no longer considered to be present in the area;

- altered generic placement;

- manuscript names, i.e. the name was never published and therefore cannot be used;

- undescribed species; and

- incorrect taxonomic placement.

To address these issues, species names were checked using a variety of resources, including the Zoological Catalogues of Australia, both printed and online versions (Hooper and Wiedenmayer 1994; Rowe and Gates 1995; Davie 2002a, 2002b; Hoese et al. 2006; ABRS 2011), online sources (Appeltans et al. 2010; Rees et al. 2011) and relevant taxonomic literature (e.g. $\mathrm{Ng}$ et al. 2008). Consultation with taxonomic experts was also undertaken to identify and correct current placement. The curator or collection manager responsible for the record and authors of manuscript names was also consulted to determine the nomenclatural status of a species.

A common practice in taxonomy is to use 'open nomenclature', i.e. qualifiers with a species name to indicate taxonomic uncertainty including '?', 'cf.' (compare with or to) and 'aff.' (affinity) (Bengtson 1988). Rationale for the use of these qualifiers includes:

- identifier was unfamiliar with the species;

- identification was preliminary but the resources to confirm the name were either not available or the database was not updated;

- specimen was damaged or juvenile with key features missing;

- characters differed from the published descriptions and variation was unknown;

- species was outside its known geographic range at the time of identification; 
- specimen differed from the species description and the type specimen would need examination to verify the name; or

- the taxonomic group required substantial revision and identification was not possible.

These qualifiers created duplication of a species name in the database, thereby affecting estimates of species richness and other diversity measures calculated on these data. When all specimens had been examined by the same identifier these records can be interpreted as an additional species. However, when collating data collected over decades and identified by multiple researchers, interpretation of the numbers of species becomes problematical. This was addressed by making standardised decisions for each record to determine if it should be included in the dataset. If a species was known from the region then the qualifier was removed and the full identification accepted. The qualifier was retained if the species was unknown in the area or there were notes to indicate why the qualifier had been applied. If the qualified identification represented an additional species then the record was retained in the dataset. If not, then the record was excluded. This was a conservative approach and the numbers of species from the region are likely to be higher than we report.

\section{SPATIAL INFORMATION, COLLECTION DETAILS AND MAPPING}

Geographical data were standardised to the nearest named island, reef or coastal feature, henceforth 'location', as per EGaz, the electronic Gazeteer of Australia (Geoscience Australia 2011). The locations of the specimen records were visualised using ARCGIS v9, ArcMap v9.3, and the data points were examined to ensure they were within the Project Area. Any outliers were examined and corrected or excluded as appropriate.

Species richness for the nine taxa covered in this project was calculated for each location across the Project Area and visualised on a map. Species richness patterns are highly dependent on sampling effort. The number of collecting events for each location was counted to generate an indicative sample effort. The precise collection date was inconsistently entered in the five source databases (WAM, WAH, AM, QM, MAGNT) creating high variability and error rates. To address this, collecting event was defined by the season (determined from month) and year of collection as these were more consistently captured in the databases.

\section{BIOGEOGRAPHIC AND HABITAT CODING}

Biogeographic and habitat codes were assigned to species to provide additional information to resource managers and researchers unfamiliar with the species. Marine species have widely differing geographic distributions, ranging from short range endemics occurring in localised areas to species with a circumglobal distribution. Within its distributional range, a species may be restricted to certain habitat types. The biogeographic ranges and preferred habitats, if known, of the species found in the Project Area were determined from the Australian Faunal Directory (AFD, ABRS 2011), other specialised literature, and personal communications with specialists. Master lists of biogeographic and habitat codes were established (Table 1 and 2 respectively). These codes are included in the species list tables for each taxon group.

\section{OVERALL DATASET}

Two hundred and seventeen locations in the Project Area had associated species data, comprising nine offshore atoll locations, one midshelf location (Browse Island) and 207 inshore locations (Appendix 2). Sampling depths were variable with locations either sampled intertidally, subtidally or a combination of both. Some recorded depths were deeper than the specified project depth of $30 \mathrm{~m}$, but were retained in the dataset as the species were known shallow water species. The number of collecting events at a location was also highly variable, ranging from 1 at 101 locations to 168 at Broome. The taxonomic groups recorded at a location were also highly variable. Sixty locations had only a single taxon recorded and eight locations (Ashmore Reef, Broome, Cape Leveque, Clerke Reef, Cockatoo Island, Lacepede Islands, Mermaid Reef and Scott Reef) had representative species from all the main taxonomic groups covered in this study.

The Project established a database exceeding 50,000 registered specimen records housed in five Australian natural science collections (Figure 2, Table 3). Of these records a total of 31,717 records were shallow water species meeting the Project criteria for inclusion in the final dataset (Table 3a). The majority of these $(21,759$ or $70 \%)$ were housed in WAM collections, with MAGNT housing the next most significant proportion (5,462 or $17 \%)$. This disparity largely reflects the geographic scope of each institution's collecting responsibilities. Within a taxonomic group, the proportional contribution of each collection to the available data varied and this was largely a function of the available expertise and research interests of scientists at these institutions. For example, there has never been a specialist 


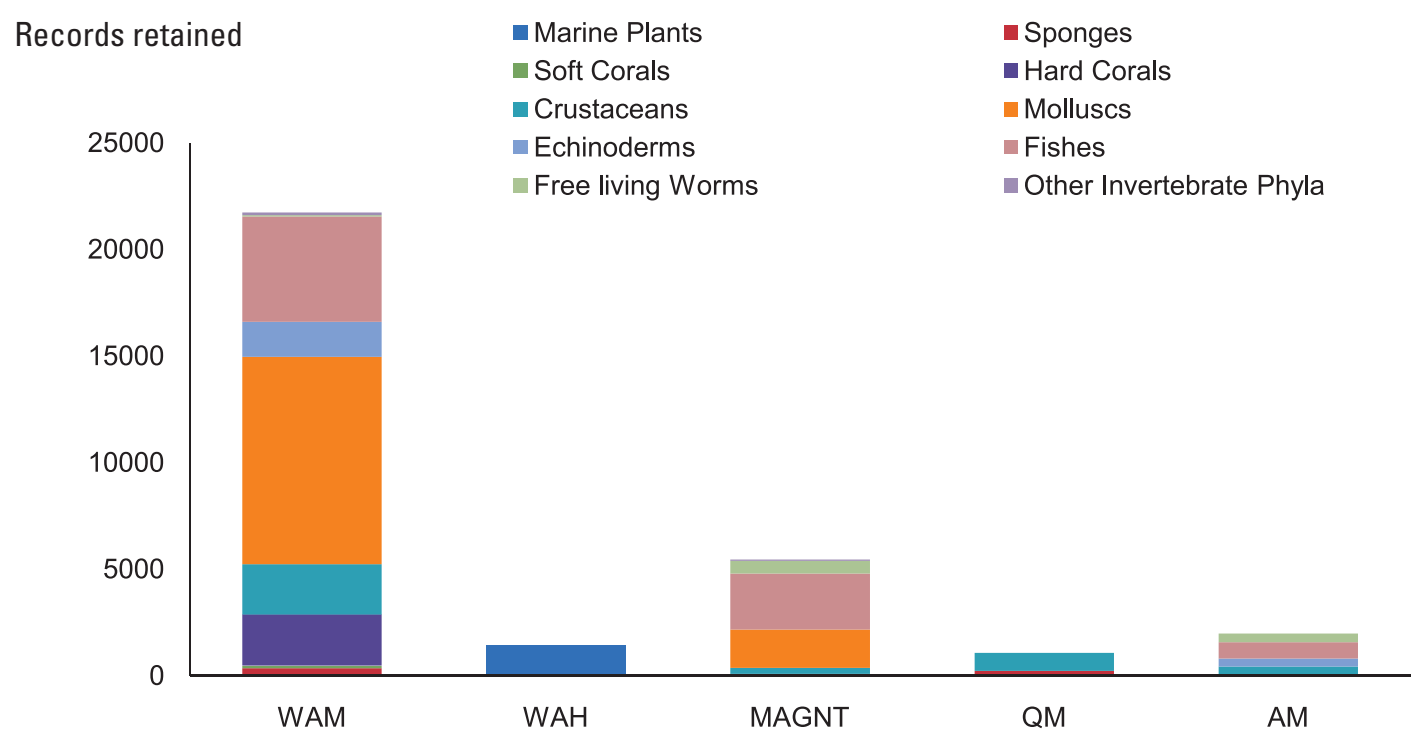

Records excluded - incomplete identification

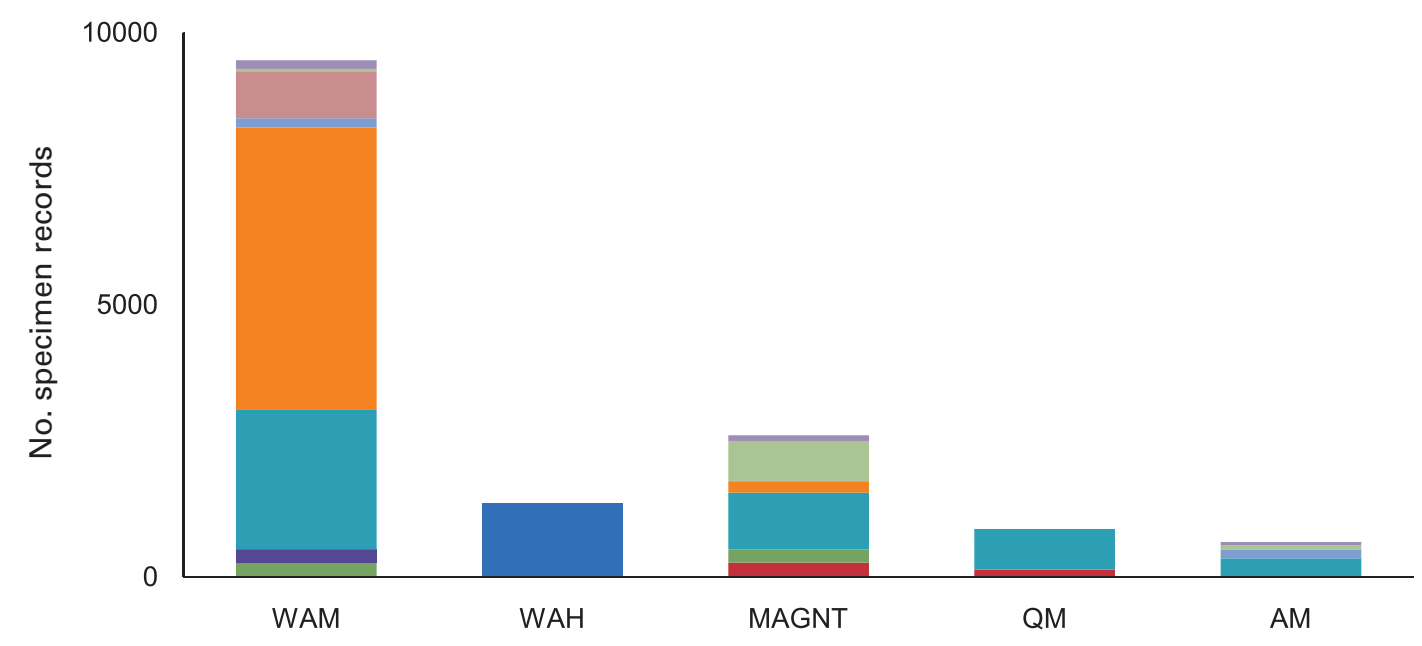

Records excluded - deepwater specimens

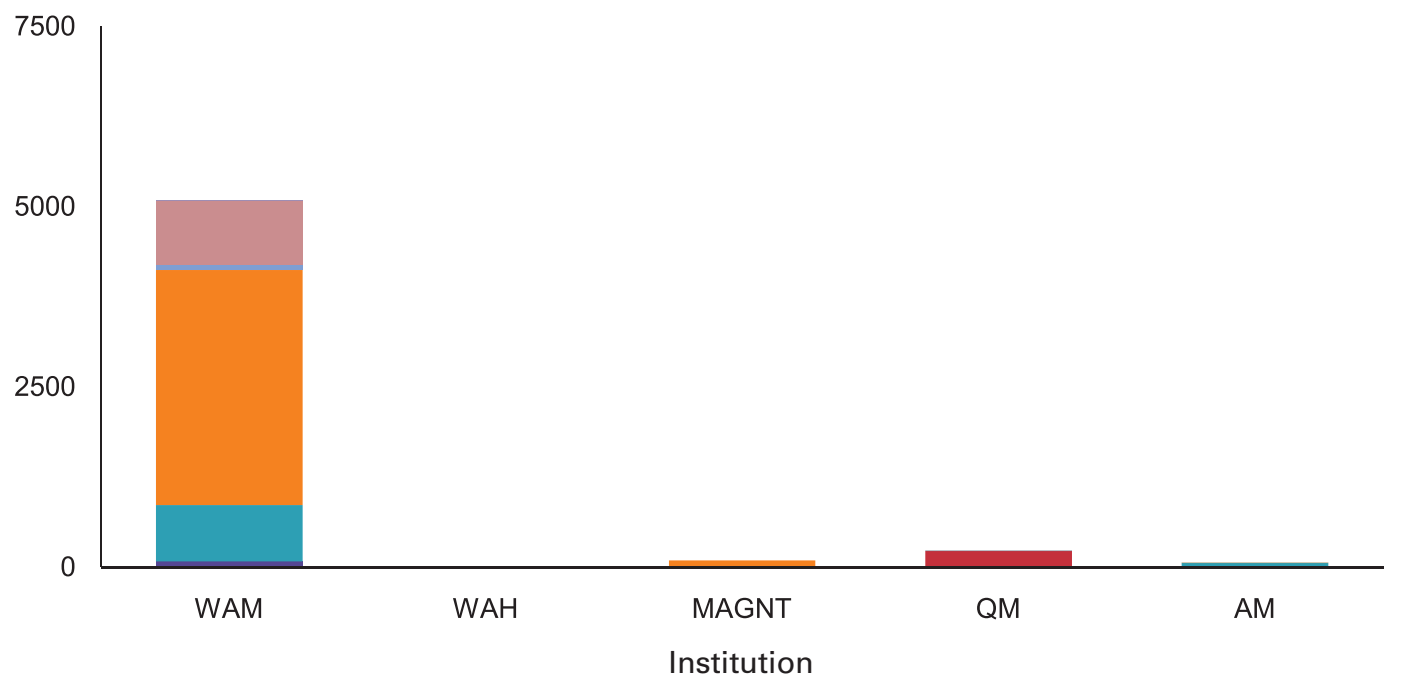

FIGURE 2 Number of registered specimen records per taxonomic group and data source. 
TABLE 1

Biogeographic Codes assigned to taxa in the Project Area.

\begin{tabular}{ll} 
Code & Definition \\
\hline WA & $\begin{array}{l}\text { Western Australian endemic. Currently known from WA waters, often only from the type locality; may } \\
\text { be a northern Australian endemic with more collecting effort. }\end{array}$ \\
NA & Northern Australian endemic. Found in tropical Australian waters. \\
SA & $\begin{array}{l}\text { Southern Australian endemic. Found in temperate Australian waters and presence in the Kimberley } \\
\text { region is the northern extent of its range. }\end{array}$ \\
A & Australian endemic. Found in tropical and temperate Australian waters. \\
IA & Indo-Australian. Found in Australian and Indonesian waters, may extend to the Philippines and \\
IO & Japan. \\
IWP & Indian Ocean. Restricted to the Indian Ocean. \\
IP & Indo-Pacific. Found in the Red Sea, Indian and Pacific Oceans. \\
WP & West Pacific. Found in the western Pacific, presence in the Kimberley region indicates occurrence in \\
T & the south eastern Indian Ocean. \\
C & Tropicopolitan. Found in all tropical oceans. \\
\hline
\end{tabular}

TABLE 2 Habitat Codes assigned to taxa in the Project Area.

\begin{tabular}{ll} 
Code & Description \\
\hline $\mathrm{i}$ & Intertidal zone. \\
$\mathrm{s}$ & Subtidal zone. \\
$\mathrm{H}$ & Associated with hard substrates (e.g. rock, coral, rubble). \\
$\mathrm{S}$ & Associated with soft substrates (e.g. sand, mud). \\
$\mathrm{P}$ & Pelagic and found in the water column; includes nektonic and planktonic species. \\
$\mathrm{E}$ & Estuarine or brackish waters. \\
$\mathrm{M}$ & Mangroves. \\
$\mathrm{SG}$ & Seagrass meadows. \\
$\mathrm{EZ}$ & Epizoic. External association with a species of animal. \\
$\mathrm{EP}$ & Epiphytic. External association with a species of marine plant. \\
EnZ & Endozoic. Living within another animal. \\
EnP & Endophytic. Living within a marine plant. \\
$\mathrm{A}$ & Amphibious. Living along the land/water interface, e.g. mudskippers. \\
$\mathrm{U}$ & Habitat of the species is unknown. \\
\hline
\end{tabular}

working on marine worms in Western Australia and this is reflected in the size of the collection (71 records or 7\%). Most of the data on Kimberley polychaetes are housed at either the MAGNT (588 or $56 \%$ ) or the AM (417 or $39 \%$ ), where there are polychaete experts. The WAH houses all the marine flora records represented in the Project Area.

14,969 shallow water specimen records were excluded from the dataset as the species were either incompletely identified, or the identification was a recently revised species (Table $3 b$ ). Reexamination of these specimens is required to verify species identity and this was beyond the scope of the current project. Fishes and corals had a low proportion of records excluded from the final dataset as most of the specimens were identified to species. By comparison, some of the marine invertebrate groups had a high proportion of records excluded as much of the collection has not been identified to species. For example, a large number of molluscs and crustaceans were excluded; 
TABLE $3 \quad$ Number of registered specimen records per taxonomic group and data source.

a) No. of specimen records retained in project data set.

\begin{tabular}{|c|c|c|c|c|c|c|}
\hline Taxa Group & WAM & WAH & MAGNT & $\mathrm{QM}$ & AM & Total \\
\hline Marine Plants & 0 & 1,430 & 0 & 0 & 0 & 1,430 \\
\hline Sponges & 365 & 0 & 60 & 238 & 2 & 665 \\
\hline Soft Corals & 109 & 0 & 29 & 0 & 2 & 140 \\
\hline Hard Corals & 2,412 & 0 & 5 & 0 & 6 & 2,423 \\
\hline Polychaetes & 45 & 0 & 588 & 0 & 413 & 1,046 \\
\hline Crustaceans & 2,358 & 0 & 274 & 835 & 426 & 3,893 \\
\hline Molluscs & 9,743 & 0 & 1,808 & 0 & 0 & 11,551 \\
\hline Echinoderms & 1,639 & 0 & 0 & 0 & 375 & 2,014 \\
\hline Fishes & 4,944 & 0 & 2,627 & 0 & 765 & 8,336 \\
\hline Other Marine Invertebrates & 154 & 0 & 71 & 0 & 4 & 229 \\
\hline Total & 21,769 & 1,430 & 5,462 & 1,073 & 1,993 & 31,727 \\
\hline
\end{tabular}

b) No. of specimen records excluded due to incomplete identification.

\begin{tabular}{lllllll} 
Taxa Group & WAM & WAH & MAGNT & QM & AM & Total \\
\hline Marine Plants & 0 & 1,343 & 0 & 0 & 0 & 1,343 \\
Sponges & 0 & 0 & 265 & 132 & 9 & 406 \\
Soft Corals & 261 & 0 & 244 & 0 & 0 & 505 \\
Hard Corals & 243 & 0 & 0 & 0 & 0 & 243 \\
Polychaetes & 35 & 0 & 697 & 0 & 80 & 812 \\
Crustaceans & 2,576 & 0 & 1,038 & 750 & 336 & 4,700 \\
Molluscs & 5,175 & 0 & 208 & 0 & 0 & 5,383 \\
Echinoderms & 169 & 0 & 0 & 0 & 156 & 325 \\
Fishes & 868 & 0 & 7 & 0 & 3 & 878 \\
Other Marine Invertebrates & 162 & 0 & 143 & 0 & 59 & 364 \\
Total & $\mathbf{9 , 4 8 9}$ & $\mathbf{1 , 3 4 3}$ & $\mathbf{2 , 6 0 2}$ & $\mathbf{8 8 2}$ & $\mathbf{6 4 3}$ & $\mathbf{1 4 , 9 5 9}$
\end{tabular}

c) No. of deepwater specimen records.

\begin{tabular}{lllllll} 
Taxa Group & WAM & WAH & MAGNT & OM & AM & Total \\
\hline Marine Plants & 0 & 0 & 0 & 0 & 0 & 0 \\
Sponges & 1 & 0 & 6 & 227 & 2 & 236 \\
Soft Corals & 9 & 0 & 0 & 0 & 0 & 9 \\
Hard Corals & 69 & 0 & 0 & 0 & 0 & 69 \\
Polychaetes & 0 & 0 & 0 & 0 & 0 & 0 \\
Crustaceans & 783 & 0 & 0 & 1 & 56 & 840 \\
Molluscs & 3,259 & 0 & 87 & 0 & 1 & 3,347 \\
Echinoderms & 74 & 0 & 0 & 0 & 0 & 74 \\
Fishes & 889 & 0 & 0 & 0 & 0 & 889 \\
Other Marine Invertebrates & 7 & 0 & 0 & 0 & 0 & 7 \\
Total & $\mathbf{5 , 0 9 1}$ & $\mathbf{0}$ & $\mathbf{9 3}$ & $\mathbf{2 2 8}$ & $\mathbf{5 9}$ & $\mathbf{5 , 4 7 1}$ \\
\hline Grand Total & $\mathbf{3 6 , 3 4 9}$ & $\mathbf{2 , 7 7 3}$ & $\mathbf{8 , 1 5 7}$ & $\mathbf{2 , 1 8 3}$ & $\mathbf{2 , 6 9 5}$ & $\mathbf{5 2 , 1 5 7}$ \\
\hline
\end{tabular}


this was frequently due to some families being very well known and described, while others are virtually unidentified. Sessile invertebrates have large numbers of specimens excluded as these were only identified to phylum, e.g. sponges and soft corals. This reflects the current state of knowledge of these taxa and indicates where work is needed.

We limited our project to shallow water species for reasons specified in the methods above. However, there were 5,471 deep water specimen records (Table 3c) in the Project Area databases. At least two major expeditions have undertaken sampling from the deeper $(30-200 \mathrm{~m})$ shelf waters in the region, the Soela (1979-1984) and the Southern Surveyor (2007). Deep water species and communities differ from those in shallow water and these records would provide additional information about the ecology of the Kimberley region.

\section{TAXONOMIC PAPERS}

This paper is the second in a series on historical natural science data of marine taxa in the Kimberley and provides a general introduction, an outline of the methods used and defines the parameters of the dataset. It will be followed by a number of papers giving a more detailed summary of each taxonomic group. Papers on current surveys (2009-2014) of targeted taxa being undertaken in the Project Area will be published separately.

\section{ACKNOWLEDGMENTS}

Thanks to Alex Chapman (Western Australian Herbarium), Gavin Dal ly and Suzanne Horner (Museum and Art Gallery of the Northern Territory), Merrick Ekins (Queensland Museum) and Stephen Keable (Australian Museum), who manage the datasets provided by the institutions. Janene Bishop assisted with data and map checking and generating the summary table of the major expeditions. Over the years many volunteers, museum staff members and international taxonomic experts have contributed to the production and maintenance of these datasets and we acknowledge their valuable contribution. Piers Higgs, Andrew Dennison, Anthony Jones, Akeal Hayek and the team at Gaia Resources are acknowledged for map production, database and GIS support. In particular, we thank Diana Jones, Jane Fromont, Glenn Moore and Sue Morrison for their helpful comments during this project and with this manuscript. Thanks to John Huisman, Richard Willan and Lisa Kirkendale for reviewing the manuscript. We thank Woodside Energy Ltd for their generous and ongoing support of WAM research.

\section{REFERENCES}

ABRS (2011). Australian Faunal Directory. Australian Biological Resources Study: Canberra, Australia; http://www.environment.gov.au/biodiversity/abrs/ online-resources/fauna/afd/index.html. Accessed 2008-2011.

Appeltans, W., Ahyong, S.T., Anderson, G., Angel, M.V., Artois, T., Bailly, N., Bamber, R., Barber, A., Bartsch, I., Berta, A., Bła冈ewicz-Paszkowycz, M., Bock, P., Boxshall, G., Boyko, C.B., Nunes Brandão, S., Bray, R.A., Bruce, N.L., Cairns, S.D., Chan, T.-Y., Cheng, L., Collins, A.G., Cribb, T., Curini-Galletti, M., Dahdouh-Guebas, F., Davie, P.J.F., Dawson, M.N., De Clerck, O., Decock, W., De Grave, S., J. de Voogd, N, Domning, D.P., Emig, C.C., Erséus, C., Eschmeyer, W., Fauchald, K., Fautin, D.G., Feist, S.W., Fransen, C.H.J.M., Furuya, H., Garcia-Alvarez, O., Gerken, S., Gibson, D., Gittenberger, A, Gofas, S., GómezDaglio, L., Gordon, D.P., Guiry, M.D., Hernandez, F., Hoeksema, B.W., Hopcroft, R. R., Jaume, D., Kirk, P., Koedam, N, Koenemann, S., Kolb, J.B., Kristensen, R.M., Kroh, A., Lambert, G., Lazarus, D.B., Lemaitre, R., Longshaw, M., Lowry, J., Macpherson, E., Madin, L.P., Mah, C., Mapstone, G., McLaughlin, P.A., Mees, J., Meland, K, Messing, C.G., Mills, C.E., Molodtsova, T.N., Mooi, R., Neuhaus, B., Ng, P.K.L., Nielsen, C., Norenburg, J., Opresko, D.M., Osawa, M., Paulay, G., Perrin, W., Pilger, J.F., Poore, G.C.B., Pugh, P., Read, G.B., Reimer, J.D., Rius, M., Rocha, R.M., Saiz-Salinas, J.I., Scarabino, V., Schierwater, B., Schmidt-Rhaesa, A., Schnabel, K.E., Schotte, M., Schuchert, P., Schwabe, E., Segers, H., Self-Sullivan, C., Shenkar, N., Siegel, V., Sterrer, W., Stöhr, S., Swalla, B., Tasker, M.L., Thuesen, E.V., Timm, T., Todaro, M.A., Turon, X., Tyler, S., Uetz, P., van der Land, J., Vanhoorne, B., van Ofwegen, L.P., van Soest, R.W.M., Vanaverbeke, J., Walker-Smith, G., Walter, T.C., Warren, A., Williams, G.C., Wilson, S.P., and Costello M.J. (2012). The magnitude of global marine species diversity. Current Biology 22(23): 2189-2202.

Appeltans, W., Bouchet, P., Boxshall, G.A., Fauchald, K., Gordon, D.P., Hoeksema, B.W., Poore, G.C.B., van Soest, R.W.M., Stöhr, S., Walter, T.C. and Costello, M.J. (eds) (2010). World Register of Marine Species. http:/ / www.marinespecies.org. Accessed 2008-2011.

Bengtson, P. (1988). Open nomenclature. Palaeontology 31(1): 223-227.

Berry, P.F. (ed.) (1986). Faunal survey of the Rowley Shoals, Scott Reef and Seringapatam Reef northwestern Australia. Records of the Western Australian Museum Supplement 25.

Berry, P.F. (ed.) (1993). Marine faunal surveys of Ashmore Reef and Cartier Island north-western Australia. Records of the Western Australian Museum Supplement 44.

Boero, F. (2010). The study of species in the era of biodiversity: a tale of stupidity. Diversity 2: 115-126.

Brown, K. and Skewes, T.D. (2005). A preliminary assessment of the ecology of seagrasses at Ashmore Reef. The Beagle, Records of the Museum and Art Galleries of the Northern Territory Supplement 1: 143-152. 
Bryce, C.W. (ed.) (2009). Marine biodiversity survey of Mermaid Reef (Rowley Shoals), Scott and Seringapatam Reefs. Records of the Western Australian Museum Supplement 77.

Bryce, C.W., Hutchins, B. and Fromont, J. (1997). Restricted marine biological survey of the 'garden bottom' of Beagle Bay, Kimberley, Western Australia. Western Australian Museum: Perth. Unpublished report.

Cotterill, F.P.D. (1995). Systematics, biological knowledge and environmental conservation. Biodiversity and Conservation 4(2): 183-205.

Davie, P.J.F. (2002a). Crustacea: Malacostraca: Phyllocarida, Hoplocarida, Eucarida (Part 1). In: Wells, A. and Houston, W.W.K. (eds), Zoological Catalogue of Australia Volume 19.3A. CSIRO: Melbourne.

Davie, P.J.F. (2002b). Crustacea: Malacostraca: Eucarida (Part 2): Decapoda-Anomura, Brachyura. In: Wells, A. and Houston, W.W.K. (eds), Zoological Catalogue of Australia Volume 19.3B. CSIRO: Melbourne.

Department of Environment and Conservation. (2009). Protecting the Kimberley. A synthesis of scientific knowledge to support conservation management in the Kimberley region of Western Australia. Department of Environment and Conservation: Perth. Unpublished report.

Funk, V.A. and Richardson, K.S. (2002). Systematic data in biodiversity studies: use it or lose it. Systematic Biology 51(2): 303-316.

Gaston, K.J. and Mound, L.A. (1993). Taxonomy, hypothesis testing and the biodiversity crisis. Proceedings: Biological Sciences 251(1331): 139-142.

Geoscience Australia (2011). Gazetteer of Australia. Australian Government: Canberra, Australia; http:/ / www.ga.gov.au/place-name/. Accessed 2008-2011.

Graham, C.H., Ferrier, S., Huettman, F., Moritz, C. and Peterson, A.T. (2004). New developments in museumbased informatics and applications in biodiversity analysis. Trends in Ecology E Evolution 19(9): 497-503.

Halpern, B.S., Walbridge, S., Selkoe, K.A., Kappel, C.V., Micheli, F., D'Agrosa, C., Bruno, J.F., Casey, K.S., Ebert, C. and Fox, H.E. (2008). A global map of human impact on marine ecosystems. Science 319(5865): 948.

Hoese, D.F., Bray, D.J., Paxton, J.R. and Allen, G.R. (2006). Fishes. In: Beesley, P.L. and Wells, A. (eds), Zoological Catalogue of Australia Volume 35(1-3). CSIRO: Melbourne.

Hooper, J.N.A. and Wiedenmayer, F. (1994). Porifera. In: Wells, A. (ed.), Zoological Catalogue of Australia. Volume 12. CSIRO: Melbourne.

Huisman, J.M. and Millar, A.J.K. (2013). Australian seaweed collections: use and misuse. Phycologia 52: 2-5.

Hutchins, J.B. (1999). Biogeography of the nearshore marine fish fauna of the Kimberley, Western Australia. Proceedings of the 5th Indo-Pacific Fish Conference. Society of French Ichthyologists: Nouméa, New Caledonia.

Johnstone, R.E. (1990). Mangrove and mangrove birds of Western Australia. Records of the Western Australian
Museum Supplement 32.

Marsh, L.M. and Marshall, J.I. (1983). Some aspects of the zoogeography of northwestern Australian echinoderms (other than holothurians). Bulletin of Marine Science 33(3): 671-687.

Morgan, G.J. (ed.) (1992). Survey of the aquatic fauna of the Kimberley islands and reefs, Western Australia. Western Australian Museum: Perth. Unpublished report.

Ng, P.K.L., Guinot, D. and Davie, P.J.F. (2008). Systema Brachyurorum: Part I. An annotated checklist of extant Brachyuran crabs of the world. The Raffles Bulletin of Zoology 17: 1-286.

O'Connell, A.F., Gilbert, A.T. and Hatfield, J.S. (2004). Contribution of natural history collection data to biodiversity assessment in national parks. Conservation Biology 18(5): 1254-1261.

Ponder, W.F., Carter, G.A., Flemons, P. and Chapman, R.R. (2001). Evaluation of museum collection data for use in biodiversity assessment. Conservation Biology 15(3): 648-657.

Pyke, G.H. and Ehrlich, P.R. (2010). Biological collections and ecological/environmental research: a review, some observations and a look to the future. Biological Reviews 85(2): 247-266.

Rees, A.J.J., Yearsley, G.K., Gowlett-Holmes, K. and Pogonoski, J. (2011). Codes for Australian Aquatic Biota (on-line version). CSIRO Marine and Atmospheric Research: Hobart, Australia; http:// www.cmar.csiro.au/caab/. Accessed 2008-2011.

Rowe, F.W.E. and Gates, J. (1995). Echinodermata. In: Wells, A. (ed.), Zoological Catalogue of Australia Volume 33. CSIRO: Melbourne.

Russell, B.C., Larson, H.K., Hutchins, J.B. and Allen, G.R. (2005). Reef fishes of the Sahul Shelf. The Beagle, Records of the Museums and Art Galleries of the Northern Territory Supplement 1: 83-105.

Sloan, N.A. and Bartier, P.M. (2009). Historic marine invertebrate species inventory: case study of a science baseline towards establishing a marine conservation area. Aquatic Conservation: Marine and Freshwater Ecosystems 19(7): 827-837.

Veron, J.E.N. and Marsh, L.M. (1988). Hermatypic corals of Western Australia: records and annotated species list. Records of the Western Australian Museum Supplement 29.

Walker, D.I. (1997) (ed.). Marine biological survey of the central Kimberley coast, Western Australia. University of Western Australia: Perth. Unpublished report.

Walker, D.I., Wells, F.E. and Hanley J.R. (1996) (eds). Marine biological survey of the eastern Kimberley, Western Australia. University of Western Australia, Western Australian Museum and Museum and Art Gallery of the Northern Territory. Unpublished report.

Wells, F.E. (ed.) (1989). Survey of the invertebrate fauna of the Kimberley islands, Western Australia. Western Australian Museum: Perth. Unpublished report.

Wells, F.E., Hanley, J.R. and Walker, D.I. (eds) (1995). Survey of the marine biota of the southern Kimberley islands, Western Australia. Western Australian Museum: Perth. Unpublished report. 
Western Australian Museum. (1981). Biological survey of Mitchell Plateau and Admiralty Gulf, Kimberley, Western Australia. Western Australian Museum: Perth.

Willan, R.C. (2005). The molluscan fauna from the emergent reefs of the northernmost Sahul Shelf, Timor Sea - Ashmore, Cartier and Hibernia Reefs; biodiversity and zoogeography. The Beagle, Records of the Museums and Art Galleries of the Northern Territory Supplement 1: 51-81.

Wilson, B.R. and Allen, G.R. (1987). Major components and distribution of marine fauna. In: Dyne, G.R. and Walton, D.W. (eds), Fauna of Australia. General Articles
Volume 1A. Australian Government Publishing Service: Canberra.

Wilson, B.R. (2014). Kimberley marine biota. History and environment. Records of the Western Australian Museum Supplement 84: 1-18.

Wood, M. and Mills, D. (eds) (2008). A turning of the tide: science for decisions in the Kimberley-Browse marine region. Western Australian Marine Science Institute: Perth. Unpublished report.

MANUSCRIPT RECEIVED 14 NOVEMBER 2013; ACCEPTED 9 MAY 2014. 


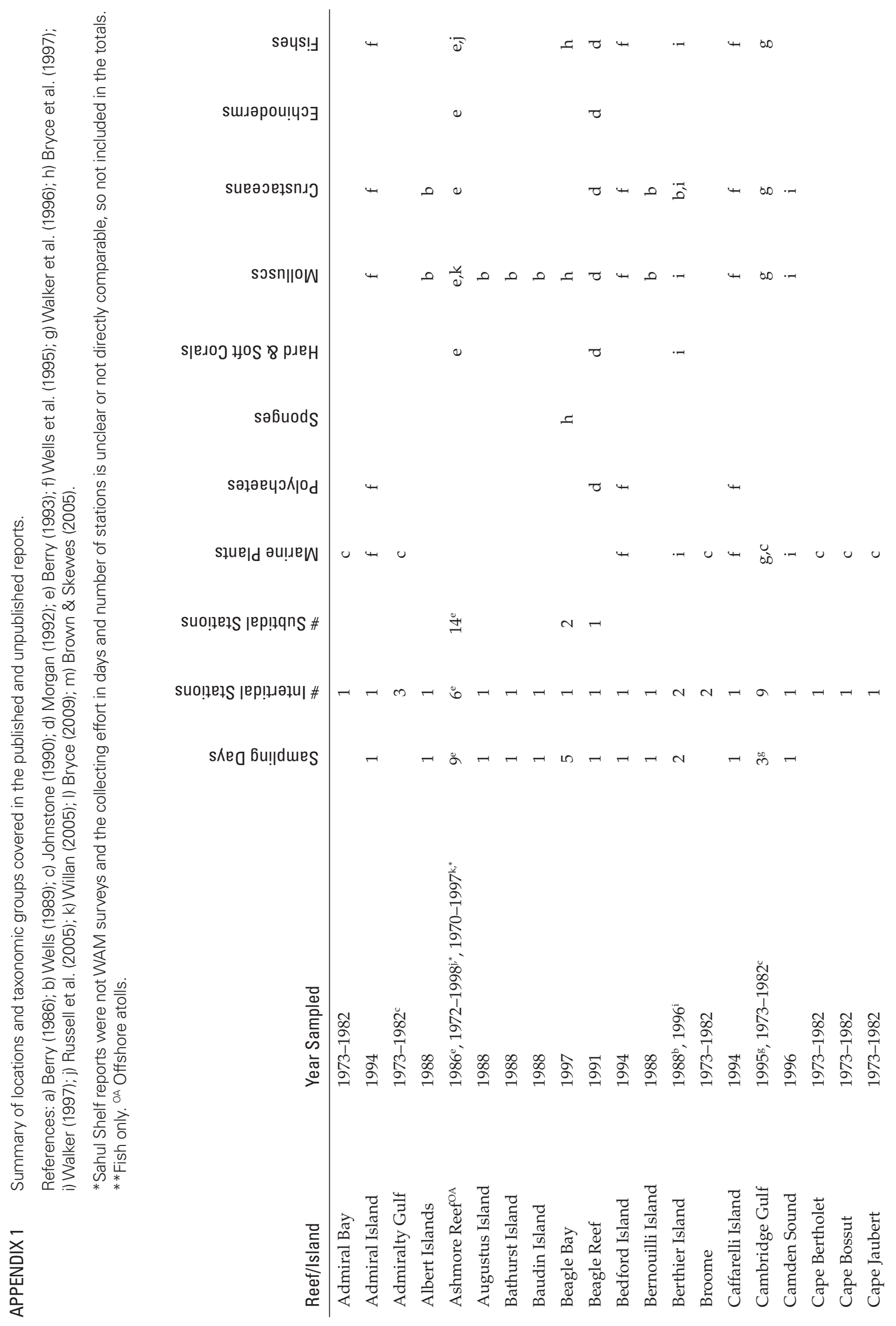




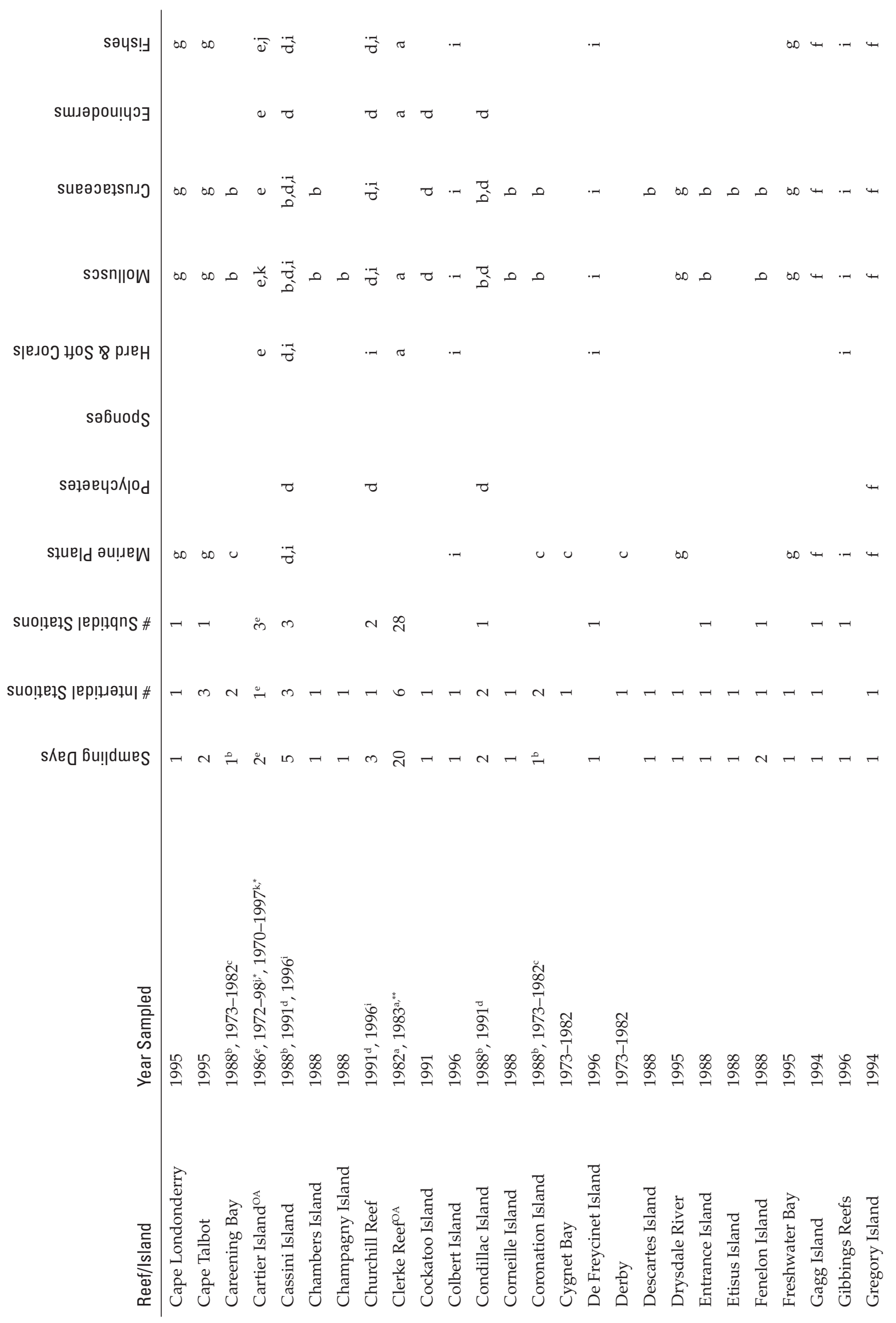




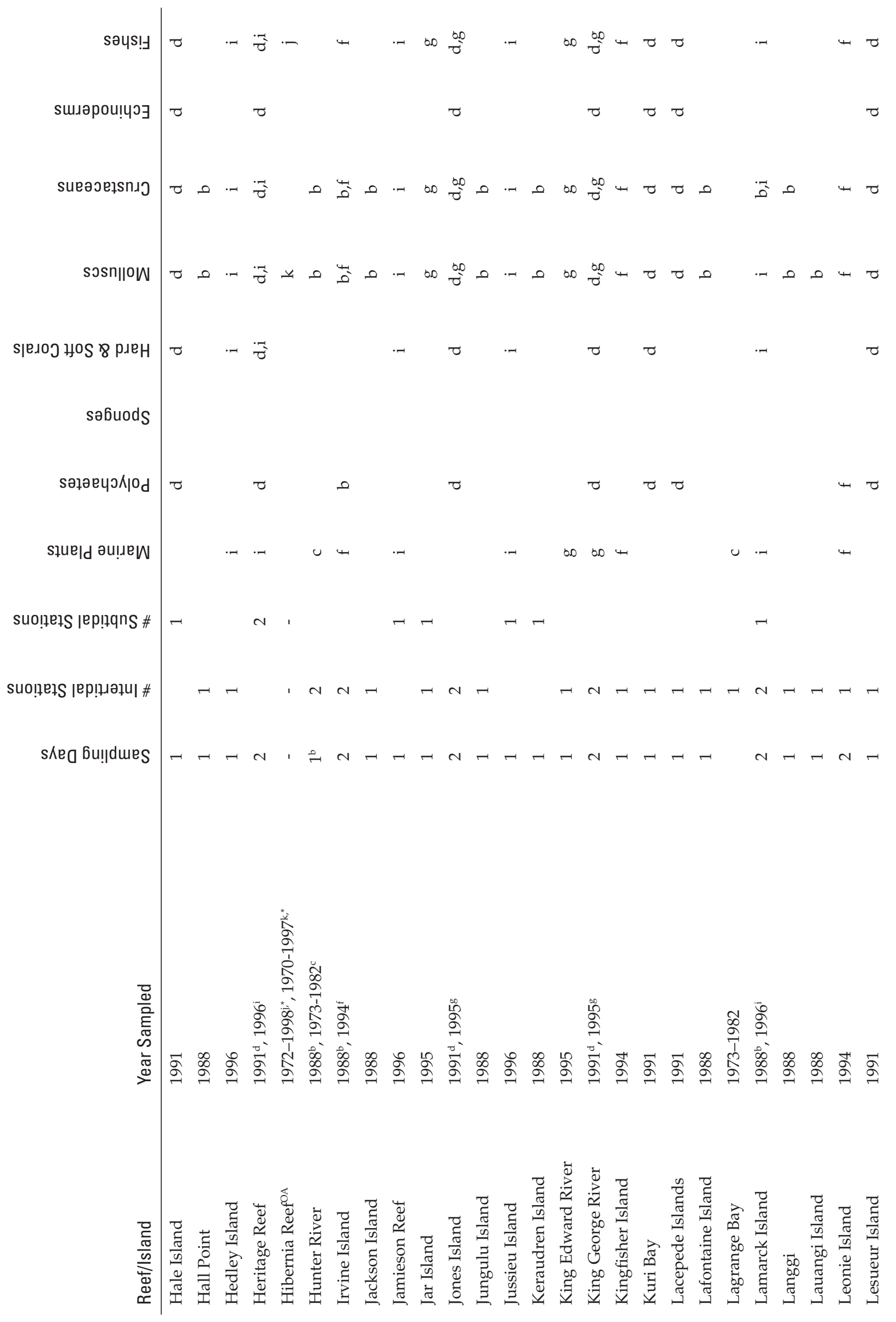




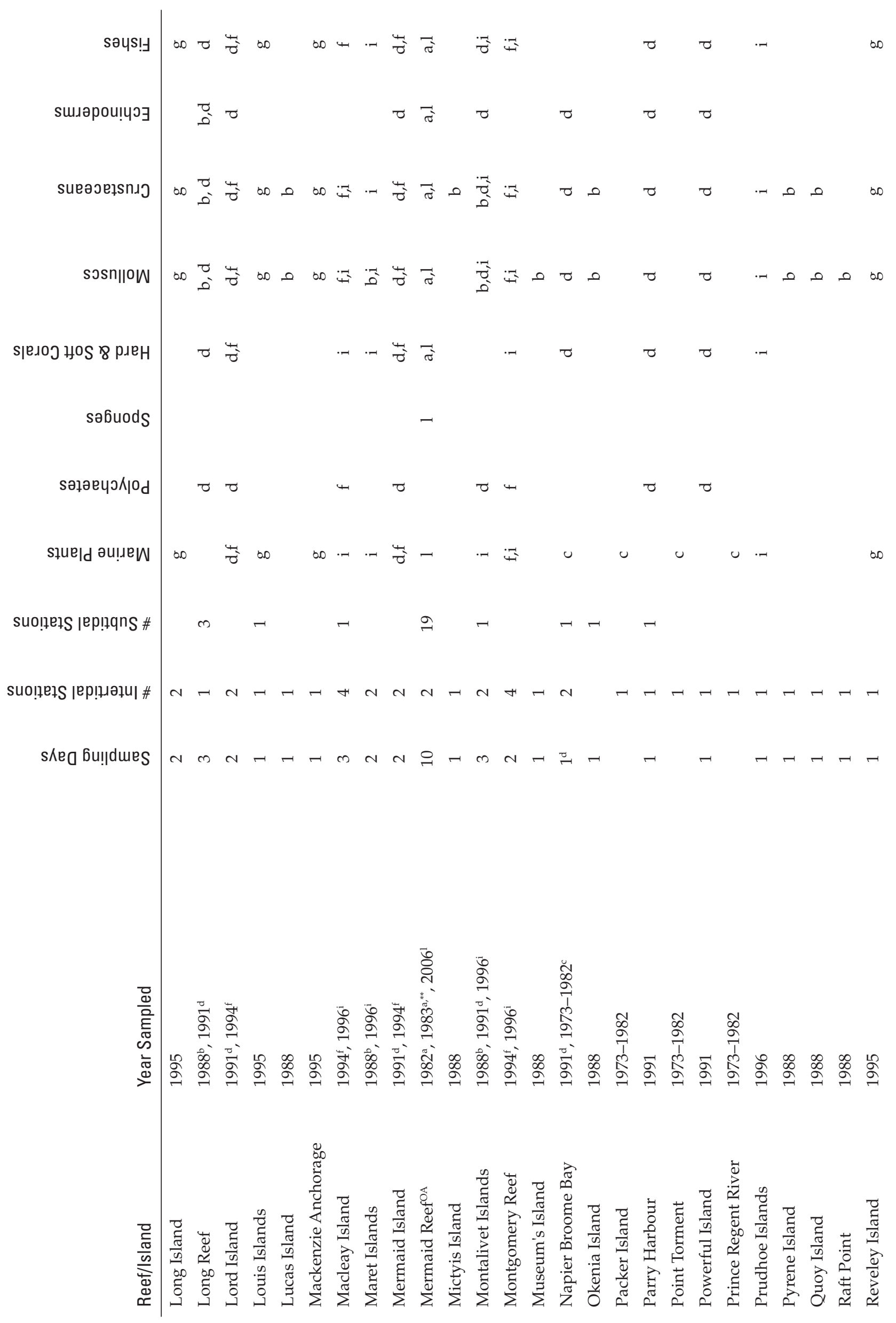




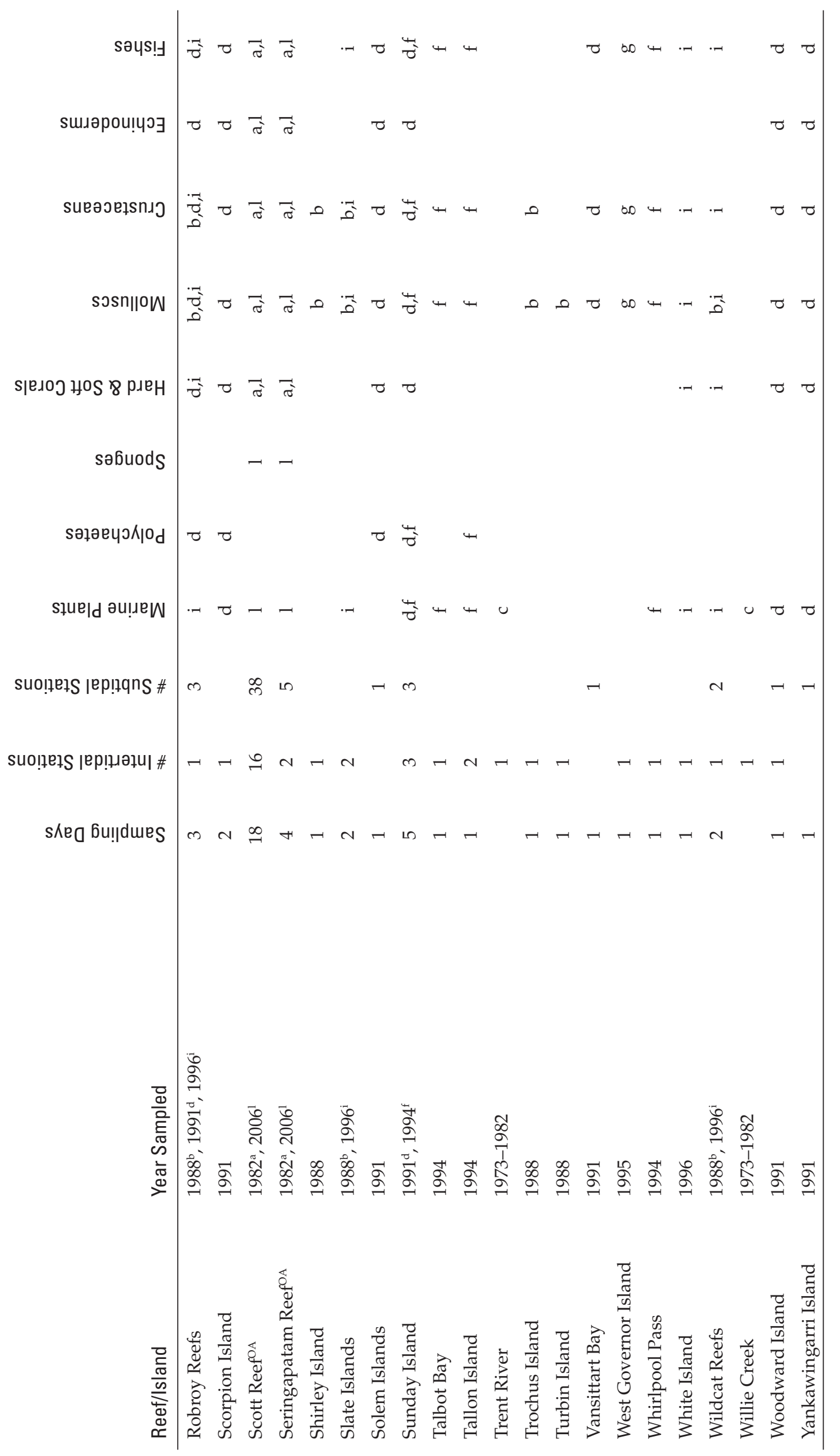



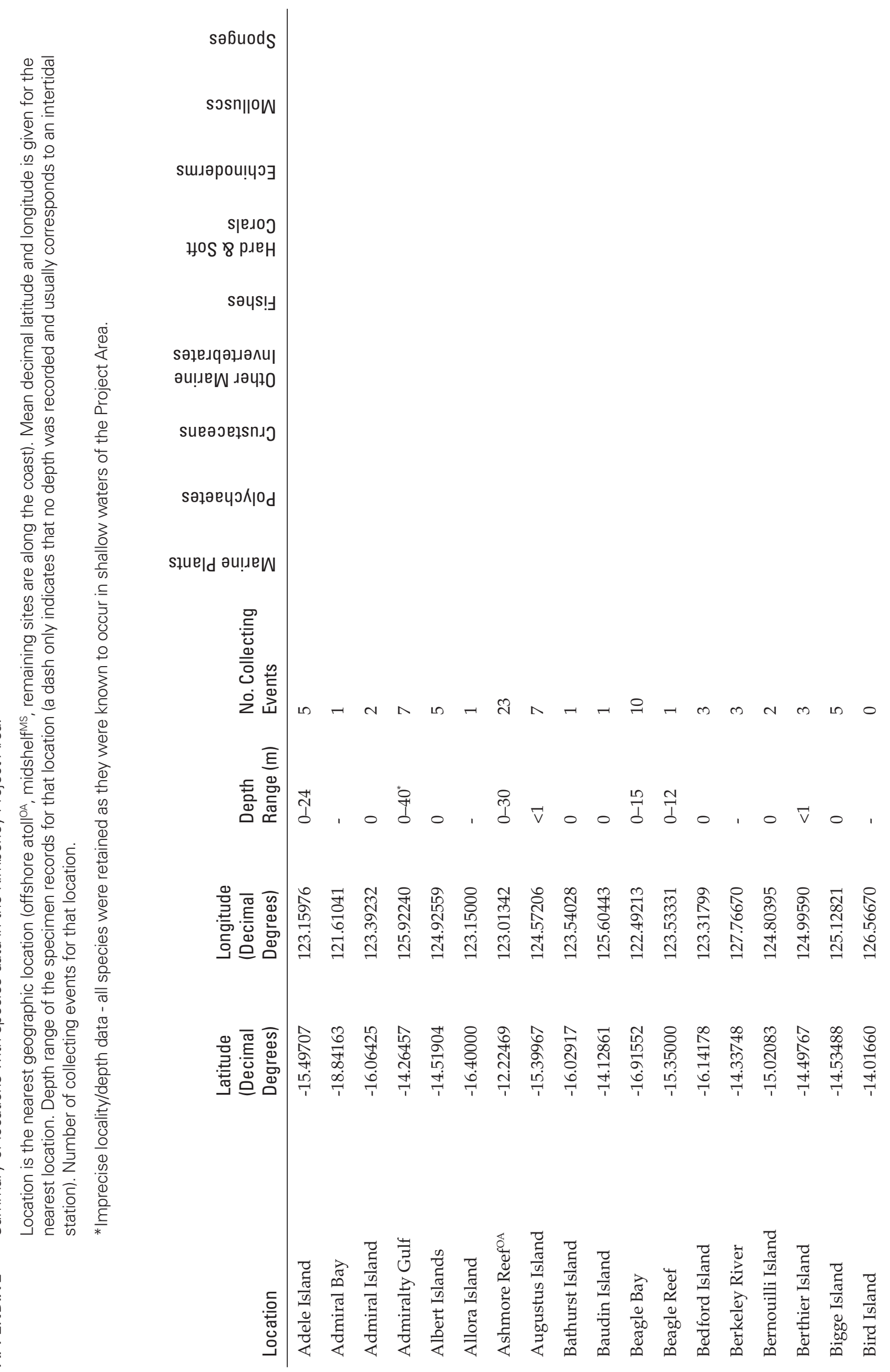


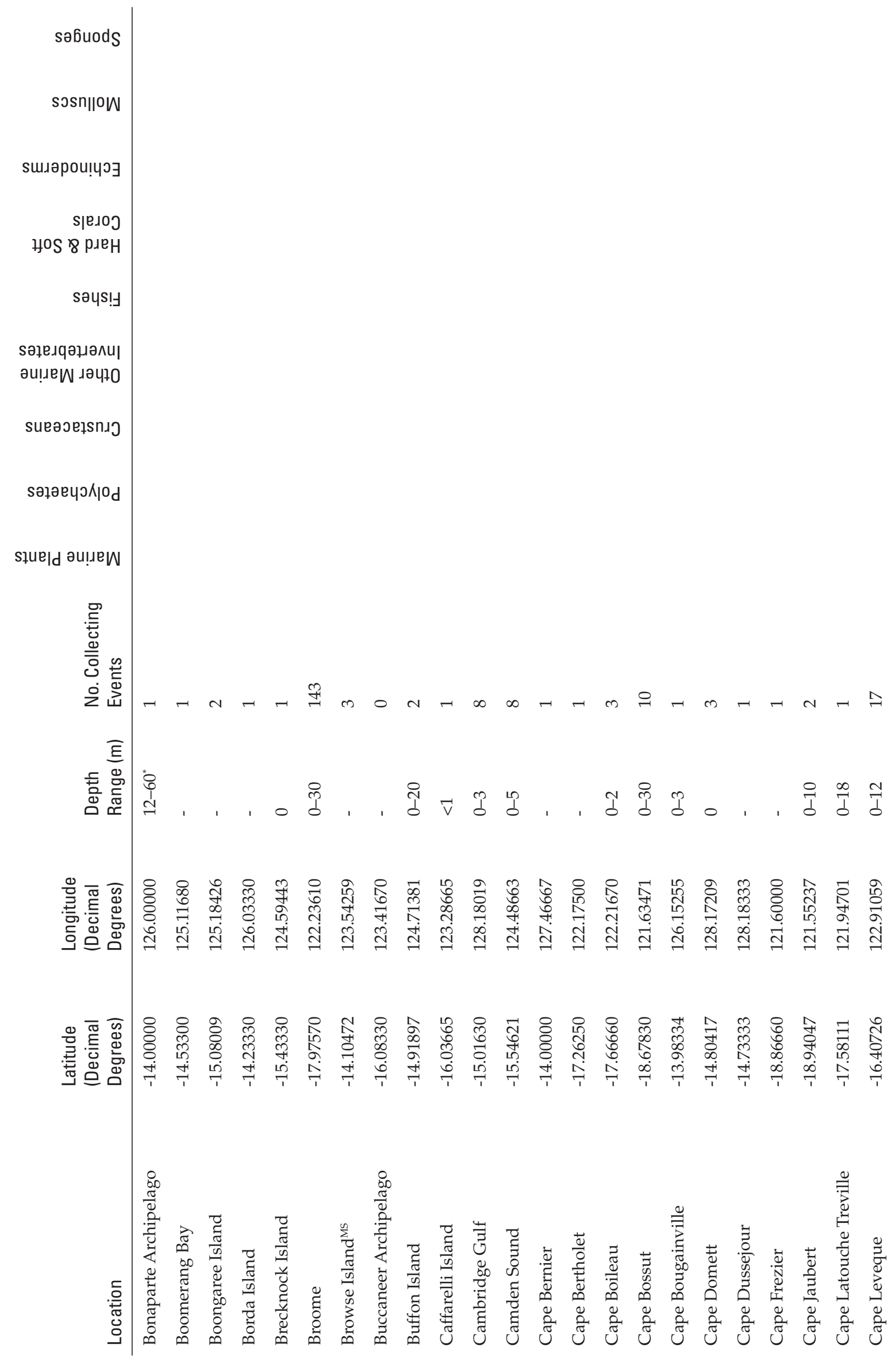




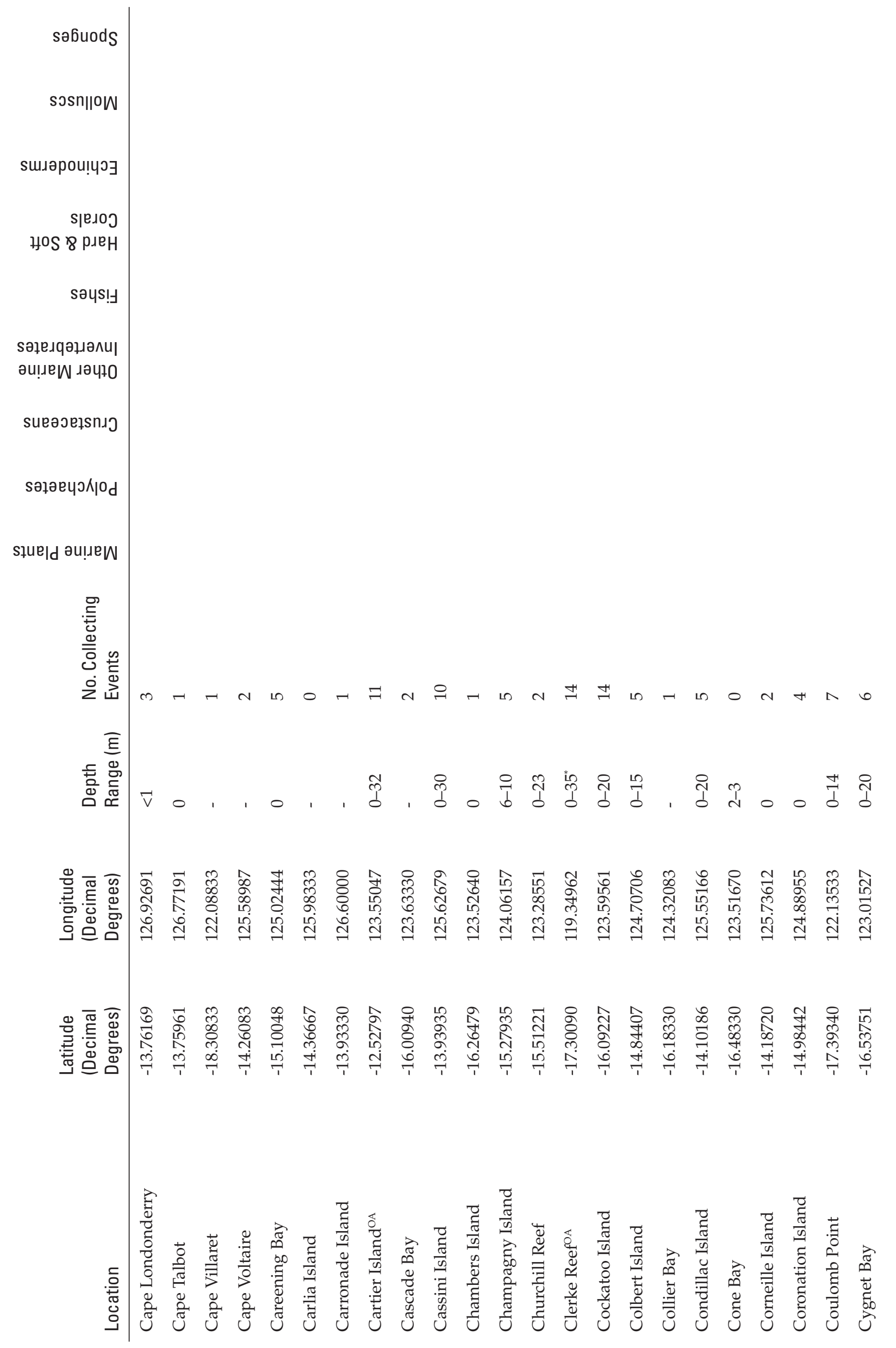




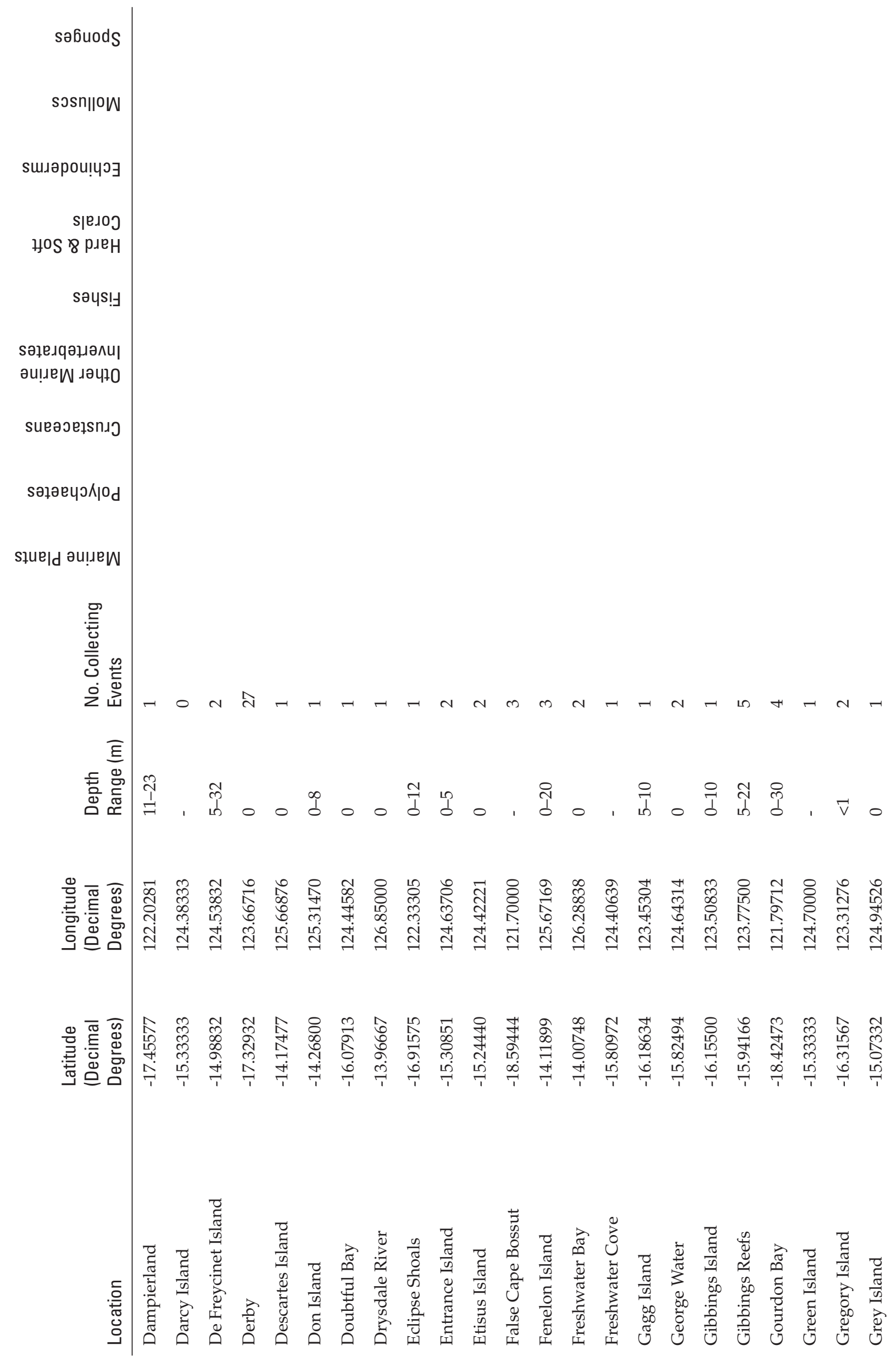




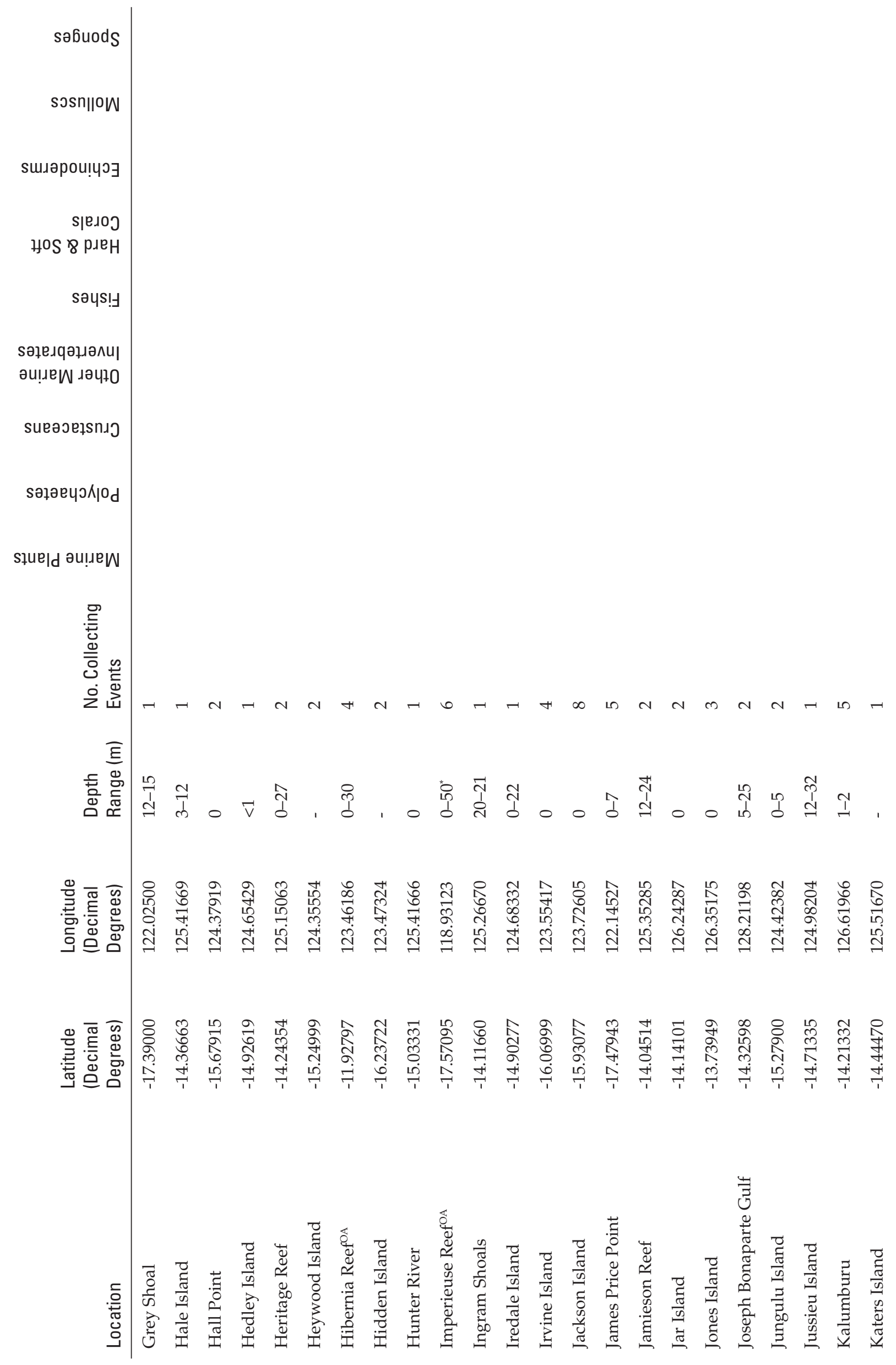




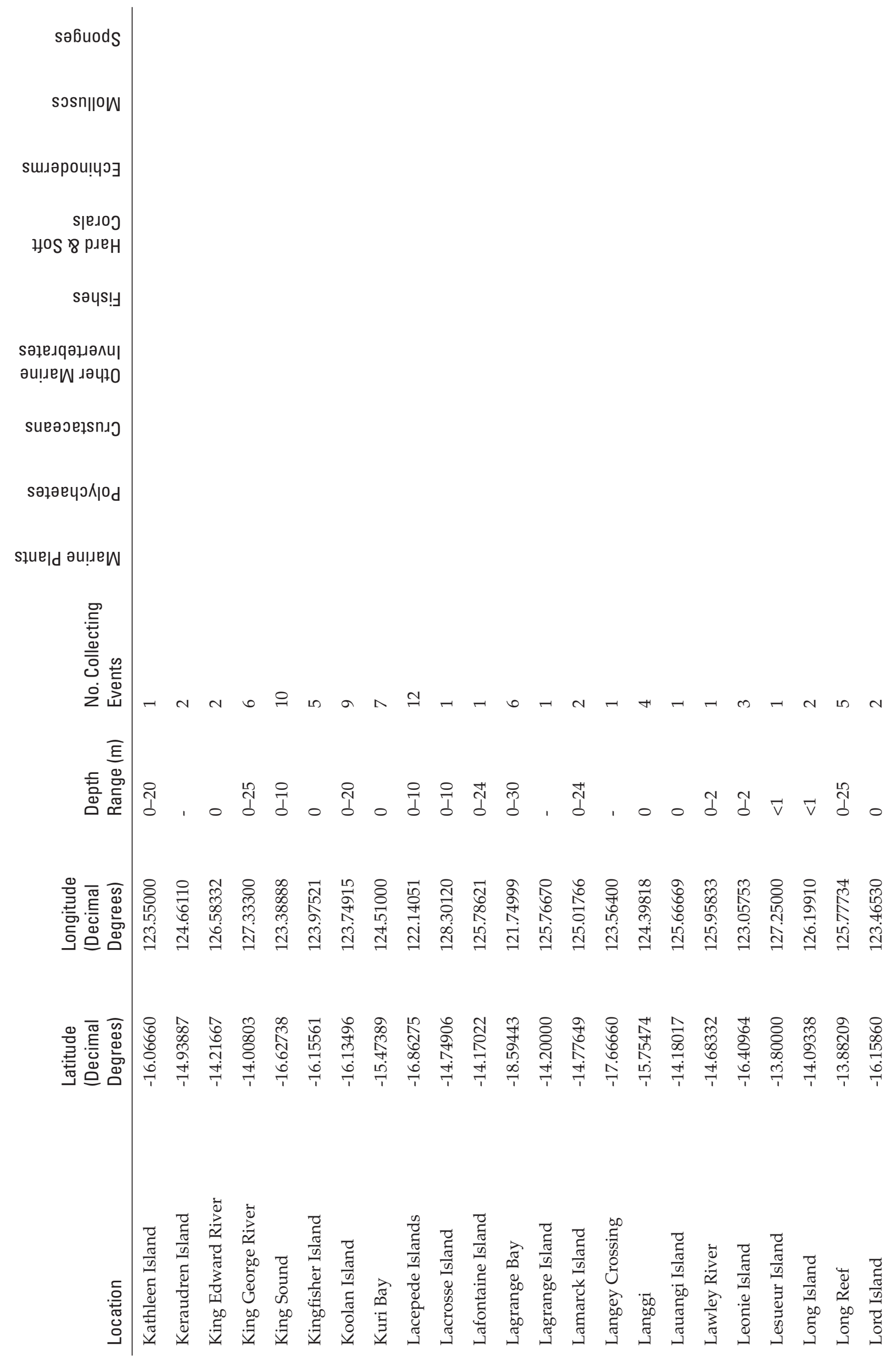




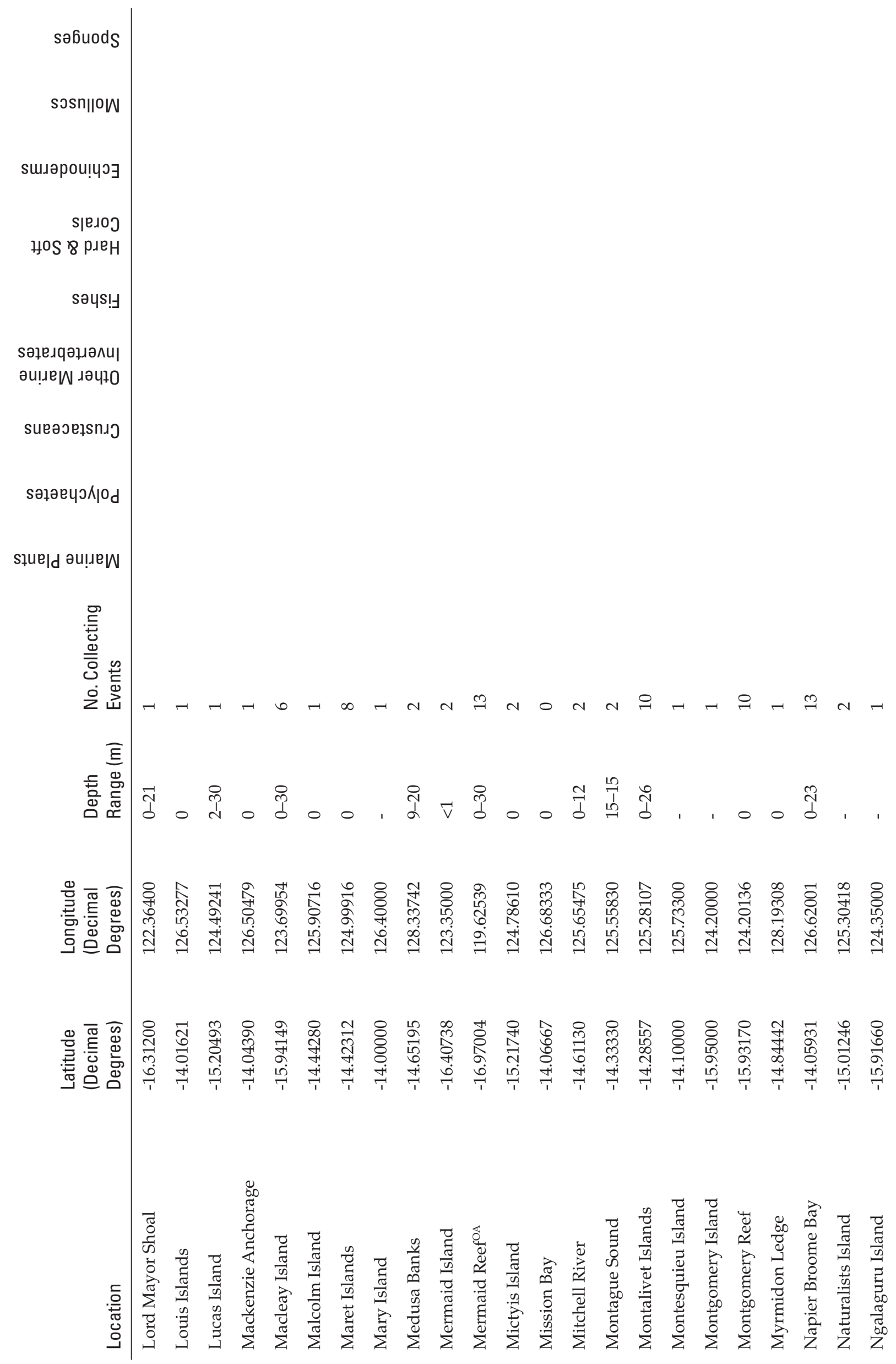




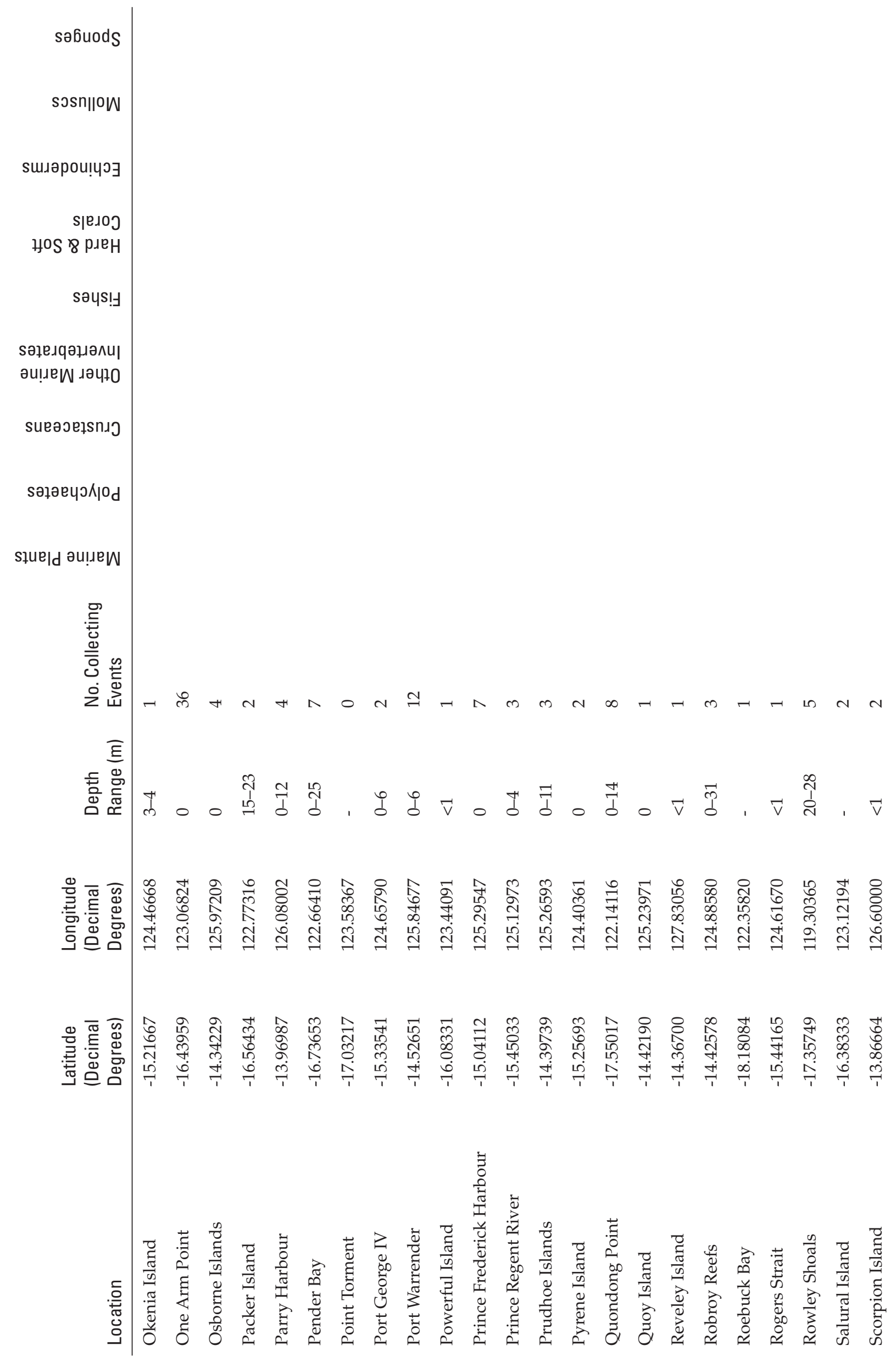




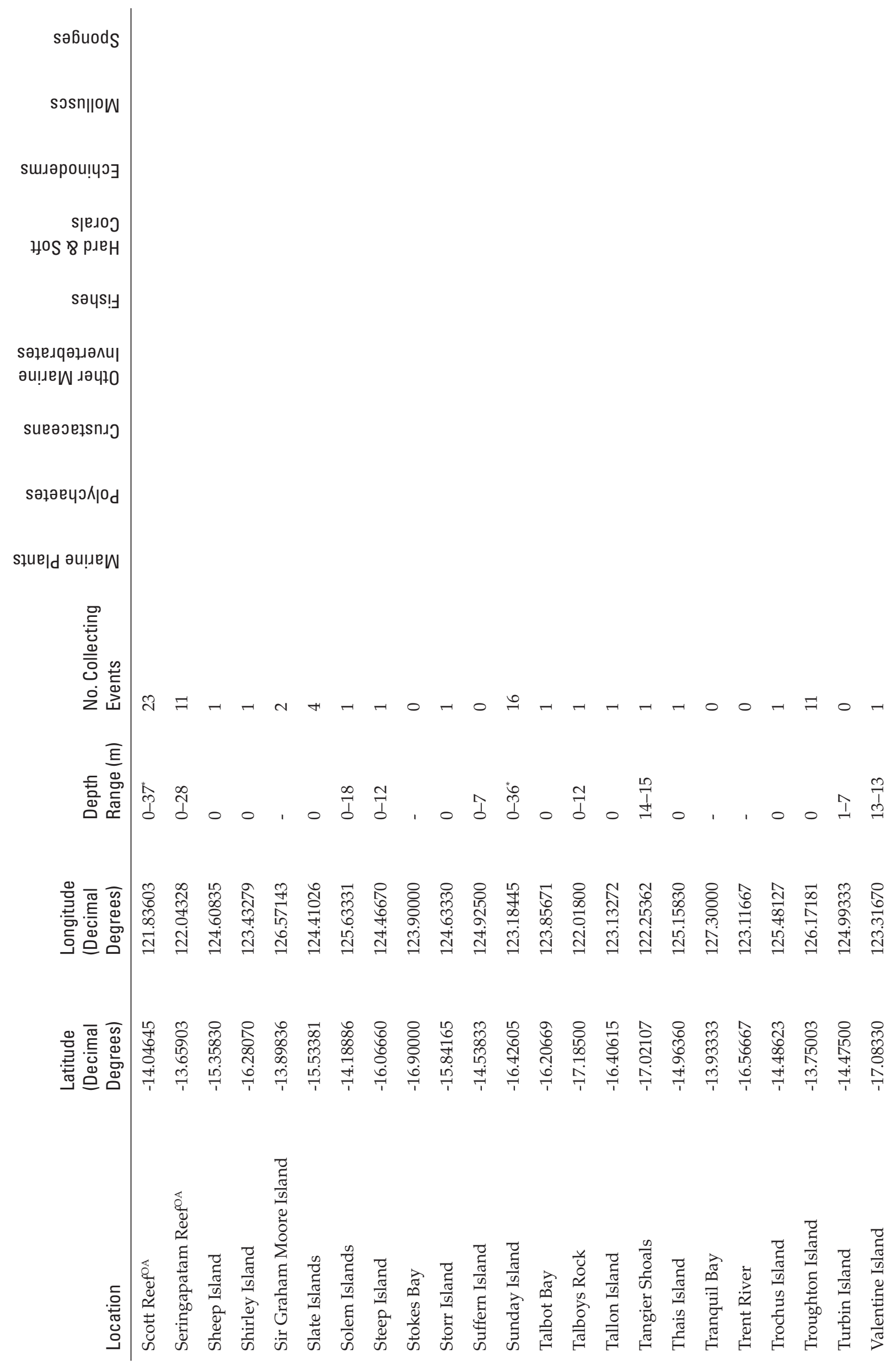




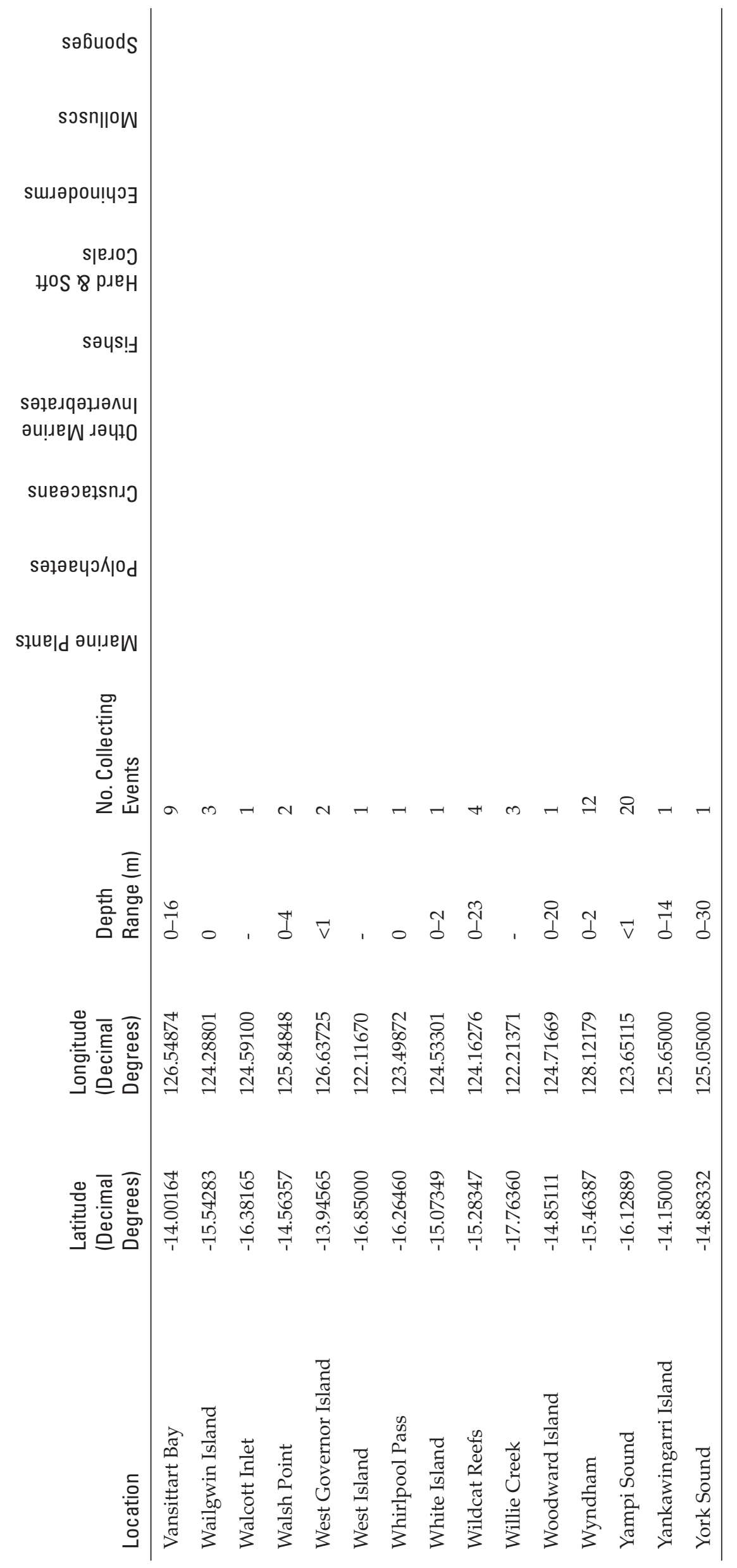

